\title{
Pengaruh Leverage, Profitabilitas, Size, Nilai Saham, Cash Holding, dan Bonus Plan terhadap Perataan Laba
}

\author{
Viktoria Angreini ${ }^{1}$, Ida Nurhayati ${ }^{2}$ \\ Universitas Stikubank Semarang, Indonesia \\ victoria.anggreini@gmail.com, ida.nurhayati@edu.unisbank.ac.id
}

*Corresponding Author

Diajukan :9 Nopember 2021

Disetujui : 20 Desember 2021

Dipublikasi : : 1 Januari 2022

\begin{abstract}
Income smoothing is one way that companies do to manipulate data. Income smoothing often occurs in companies that experience losses and report profits for the next period, so that profits will look stable for the following period and the previous period, for example in a manufacturing company in the consumer goods industry sub-sector. Internal and external parties will pay attention to several factors that affect income smoothing within the company. This study aims to analyze and examine the effect of leverage, profitability, firm size, cash holding, and bonus plan on income smoothing. The population used in this study is the consumer goods industrial sub-sector manufacturing companies listed on the Indonesia Stock Exchange (IDX) in the last five years, namely 2016-2020 with a final sample of 142. The sampling method used in this study was using atechnique. Purposivesampling. The data analysis technique uses multiple regression analysis using the SPSS 26 program. The results of this study partially explain that leverage, profitability, company size, cash holding, and bonus plans affect income smoothing, while simultaneously forvariables leverage have no effect on income smoothing., the size of the company has no effect on income smoothing, and the bonus plan has no effect on income smoothing, while the profitability variable has a positive effect and cash holding has a positive effect on income smoothing.
\end{abstract}

Keywords: bonus plan; cash hoding; firm size; leverage;share value; and profitability.

\begin{abstract}
ABSTRAK
Perataan laba merupakan salah satu cara yang dilakukan perusahaan untuk melakukan manipulasi data. Perataan laba sering terjadi pada perusahaan yang mengalami kerugian dan untuk periode berikutnya melaporkan laba, sehingga laba akan terlihat stabil untuk periode setelahnya maupun periode sebelumnya, salah satu contoh pada perusahaan manufaktur subsektor industri barang konsumsi. Pihak internal maupun eksternal akan memperhatikan beberapa faktor yang mempengaruhi perataan laba dalam perusahaan. Penelitian ini bertujuan untuk menganalisis dan menguji pengaruh leverage, profitabilitas, ukuran perusahaan, cash holding, dan bonus plan terhadap perataann laba. Populasi yang digunakan pada penelitian ini yaitu perusahaan manufaktur subsektor industri barang konsumsi yang terdaftar di Bursa Efek Indonesia (BEI) pada lima periode tahun terakhir yaitu tahun 2016-2020 dengan jumlah sampel akhir 142 Metode Pengambilan sampel yang digunakan pada penelitian ini yaitu menggunakan teknik purposive sampling. Teknik analisis data menggunakan analisis regresi berganda dengan menggunakan program SPSS 26. Hasil dari penelitian ini menjelaskan secara parsial bahwa leverage, profitabilitas, ukuran perusahaan, cash holding, dan bonus plan berpengaruh terhadap perataan laba, sedangkan secara simultan untuk variabel leverage tidak berpengaruh terhadap perataan laba, ukuran perusahaan tidak berpengaruh terhadap perataan laba,
\end{abstract}


dan bonus plan tidak berpengaruh terhadap perataan laba, sedangkan untuk variabel profitabilitas berpengaruh positif dan cash holding berpengaruh positif terhadap perataan laba.

Kata Kunci : Bonus Plan; Cash Holding; Leverage; Nilai Saham; Perataan Laba; Profitabilitas; Ukuran Perusahaan

\section{PENDAHULUAN}

Informasi laba menjadi salah satu informasi yang diungkapkan dalam laporan laba rugi dan sering kali mendapatkan perhatian yang lebih dari pengguna laporan keuangan internal maupun eksternal. Apabila laba perusahaan berfluktuatif, maka investor akan berfikir kembali untuk melakukan investasi di perusahaan tersebut, hal ini dapat mendorong timbulnya praktik perataan laba. Perataan laba merupakan salah satu cara yang digunakan manajemen untuk manipulasi (Ditiya dan Sunarto, 2019). Femomena praktik perataan laba pernah terjadi pada kasus PT Akasha Wira International Tbk (ADES), dimana PT Akasha Wira International Tbk (ADES) dalam tahun berjalan memperoleh laba $\mathrm{Rp}$ 135,78 miliar, atau naik 62,65\% dibandingkan tahun 2019 sebesar Rp 83,885 miliar. (Pasardana.id, 2020). Menurut Putra dan Suardana (2016) aktivitas laba yang diterapkan manajemen dapat berakibat akan muncul kesalahan dalam pengambilan keputusan terkhusus pihak eksternal. Ada beberapa faktor yang dapat mempengaruhi perataan laba dalam perusahaan yaitu leverage, profitabilitas, ukuran perusahaan, nilai saham, cash holding, dan bonus plan.

Faktor yang mempengaruhi manajemen dalam penerapan perataan laba seperti leverage. Leverage menunjukan seberapa besar utang yang digunakan untuk membiayai investasinya (Ditiya dan Sunarto, 2019). Dalam penelitian terdahulu menyatakan bahwa leverage berpengaruh signifikan terhadap perataan laba (Ditiya dan Sunarto, 2019). Sedangkan penelitian lain menyatakan sebaliknya, bahwa leverage tidak berpengaruh terhadap perataan laba (Setyani dan Wibowo, 2019; Revinsia, Rahayu, dan Lestari, 2019; Dewi dan Suryanawa, 2019).

Profitabilitas merupakan kemampuan perusahaan dalam menciptakan laba dari aktivitas operasi yang dilakukan dalam periode yang ditetapkan (Setyani dan Wibowo, 2019). Apabila, profitabilitas yang dihasilkan perusahaan rendah itu menunjukan kinerja perusahaan yang kurang baik. Pada penelitian terdahulu menyatakan bahwa profitabilitas berpengaruh signifikan positif terhadap perataan laba (Ditiya dan Sunarto, 2019). Penelitian lain menyatakan bahwa profitabilitas tidak berpengaruh signikan terhadap perataan laba (Revinsia, Rahayu, dan Lestari, 2019; Setyani dan Wibowo, 2019; Dewi dan Suryanawa, 2019).

Ukuran perusahaan dapat diartikan sebagai besar atau kecilnya kekayaan yang dimiliki perusahaan. Perusahaan yang memiliki kekayaan yang besar akan melakukan pembayaran pajak yang tinggi pula, maka dari itu manajer berusaha melakukan praktik perataan laba dalam perusahaan. Dalam penelitian terdahulu menyatakan bahwa ukuran perusahaan berpengaruh signifkan terhadap perataan laba (Ditiya dan Sunarto, 2019). Sedangkan penelitian lain menyatakan bahwa ukuran perusahaan tidak berpengaruh signifikan terhadap perataan laba (Choerunnisa dan Muslih, 2020; Setyani dan Wibowo, 2019).

Nilai saham yang mengalami kenaikan akan membuat perusahaan tersebut melakukan perataan laba. Dalam Penelitian sebelumnya menyatakan bahwa nilai saham bepengaruh negatif signifikan terhadap perataan laba (Yulia, 2017). Pada penelitian yang lain menyatakan bahwa nilai saham tidak berpengaruh positif signifikan terhadap perataan laba (Dewi, Mukhtarudin dan Prayudha, 2018).

Cash Holding merupakan kas yang dimiliki perusahaan dan digunakan untuk kegiatan perusahaan. Sifat dari cash holding itu sendiri adalah mudah dicairkan dalam jangka pendek. Semakin besar cash holding maka perusahaan juga melakukan perataan semakin besar pula. Penelitian sebelumnya menyatakan bahwa cash holding berpengaruh positif dan signifikan terhadap perataan laba (Nirmanggi dan Muslih, 2020). Dalam penelitian lain menyatakan bahwa cash holding tidak berpengaruh secara positif terhadap perataan laba (Choerunnisa dan Muslih, 2020).

Bonus Plan merupakan salah satu faktor yang diduga mempengaruhi perataan laba dalam perusahaan. Menurut Nugroho dan Darsono (2015) Bonus Plan adalah bentuk penghargaan yang diberikan untuk kinerja manajer dalam bentuk kompensasi bonus. Maka dari itu, manajer akan 
memotivasi diri dengan berusaha mewujudkan laba sesuai dengan tujuan yang telah ditetapakan, dengan melakukan penerapan perataan laba. Dalam penelitian terdahulu menyatakan bahwa bonus plan berpengaruh positif terhadap perataan laba (Dewi dan Suryanawa, 2019). Penelitian lain menyatakan bahwa bonus plan tidak berpengaruh terhadap perataan laba (Nirmanggi dan Muslih, 2020).

Dalam penelitian ini terdapat fenomena, research gap, perbedaan objek dan pengukuran yang digunakan peneliti. Peneliti terdahulu menggunakan objek penelitian perusahaan manufaktur dan perusahaan pertambangan yang terdaftar di Bursa Efek Indonesia dan untuk laba yang digunakan yaitu laba tahun berjalan, sedangkan penulis menggunakan objek penelitian perusahaan industri barang konsumsi yang terdaftar di Bursa Efek Indonesia dan untuk laba menggunakan laba kompherensif. Sehingga penelitian ini bertujuan untuk menguji dan menganalisa pengaruh leverage, profitabilitas, size, nilai saham, cash holding, dan bonus plan terhadap perataan laba pada perusahaan industri barang konsumsi yang terdaftar di Bursa Efek Indonesia tahun 2016 sampai dengan 2020. Penelitian ini diharapkan dapat memberikan manfaat dan informasi yang terkait dengan perataan laba dengan variabel yang digunakan peneliti untuk pengambilan keputusan bagi pihak internal maupun eksternal, serta dapat digunakan untuk acuan peneliti selanjutnya.

\section{Pengaruh Leverage Terhadap Perataan Laba}

Leverage adalah salah satu rasio yang digunakan untuk mengetahui sejauh mana perusahaan bisa membiayai utang yang ada (Wiagustini, 2014:88). Berdasarkan teori agency yang menjelaskan bahwa manajer lebih mengetahui kondisi perusahaan dibandingkan dengan kreditur. Maka dari itu, manajer akan melakukan hal - hal untuk menstabilkan hutang perusahaan, bersamaan itu laba perusahaan harus konsisten bahkan meningkat supaya perusahaan akan dianggap baik dalam melakukan pengelolaan hutangnya. Pernyataan tersebut sejalan dengan penelitian Ditya dan Sunarto (2019), dan Yulia (2017) yang menyatakan bahwa leverage berpengaruh positif terhadap perataan laba.

\section{H1 : Leverage berpengaruh positif terhadap perataan laba}

\section{Pengaruh Profitabilitas Terhadap Perataan Laba}

Profitabilitas adalah salah satu rasio yang digunakan untuk mengetahui kemampuan perusahaan dalam mencari keuntungan (Natalie dan Astika, 2016). Berdasarkan teori agency manajer akan dinilai memiliki kinerja yang baik ketika perusahaan mempunyai profitabilitas yang tinggi, ini berarti bahwa manajer bekerja sesuai dengan keinginan pemilik perusahaan. Pernyataan tersebut sejalan dengan penelitian Ditya dan Sunarto (2019), dan Yulia (2017), yang menyatakan bahwa profitabilitas berpengaruh positif terhadap perataan laba.

\section{H2 : Profitabilitas berpengaruh positif terhadap perataan laba}

\section{Pengaruh Ukuran Perusahaan Terhadap Perataan Laba}

Menurut Yusrilandari (2016) mengungkapkan bahwa ukuran perusahaan merupakan skala untuk penggolongan besar atau kecilnya suatu perusahaan. Berdasarkan teori akuntansi positif tentang hipotesis biaya politik, manajer akan dominan menentukan metode akuntansi yang tepat untuk menurunkan laba apabila diikuti dengan tingginya biaya politik perusahaan.Semakin besar perusahaan tersebut maka, akan membuat pihak eksternal memberikan perhatian lebih. Pernyataan tersebut sejalan dengan penelitian Ditya dan Sunarto (2019), dan Yulia (2017) yang menyatakan bahwa ukuran perusahaan berpengaruh positif terhadap perataan laba.

\section{H3 : Ukuran perusahaan berpengaruh positif terhadap perataan laba}

\section{Pengaruh Nilai Saham Terhadap Perataan Laba}

Nilai saham merupakan pencapaian investor selaku penanam modal yang sering dihubungkan dengan nilai perusahaan (Safitri, Arbar, dan Santoso, 2018). Berdasarkan teori signal (signaling theory), perusahaan akan mendapatkan berita atau sinyal yang baik dari investor apabila perusahaan memiliki informasi yang baik pula. Semakin tinggi nilai saham maka perusahaan 
tersebut akan meminimalisir praktik perataan laba. Terdapat pada penelitian Yulia (2018) yang menyatakan bahwa nilai saham berpengaruh negatif terhadap perataan laba.

\section{H4 : Nilai saham berpengaruh negatif terhadap perataan laba}

\section{Pengaruh Cash Holding Terhadap Perataan Laba}

Cash holding merupakan salah satu aset perusahaan uang digunakan oleh manajer sebagai alat untuk menjalankan kegiatan perusahaan (Putri dan Budiasih, 2018). Berdasarkan agency theory, adanya konflik antara manajer dan pemegang saham menyebabkan timbulnya keinginan manajemen untuk menguasai kas yang ada di perusahaan. Semakin besar cash holding maka besar kemungkinan perusahaan melakukan tindakan perataan laba. Hal ini sejalan dengan penelitian Nirmanggi dan Muslih (2020), Choerunnisa dan Muslih (2020) yang menyatakan hasil cash holding berpengaruh positif terhadap perataan laba.

\section{H5 : Cash Holding berpengaruh positif terhadap perataan laba}

\section{Pengaruh Bonus Plan Terhadap Perataan Laba}

Adanya kesepakatan mengenai kompensasi bonus ini, memungkinkan manajemen akan berjuang dengan usaha yang maksimal untuk mencapai tujuan atau target laba supaya berhak mendapatkan bonus Nugroho dan Darsono (2015). Berdasarkan agency theory disini pihak manajer yang mempunyai kepentingan untuk memperoleh bonus, lalu melakukan peningkatan bonus yang diterima. Apabila nilai dari bonus plan semakin tinggi maka perusahaan tersebut melakukan penerapan perataan laba. Hal ini didukung dengan hasil penelitian Dewi dan Suryanawa (2019) yang menyatakan bahwa bonus plan berpengaruh positif terhadap perataan laba.

\section{H5 : Bonus Plan berpengaruh positif terhadap perataan laba}

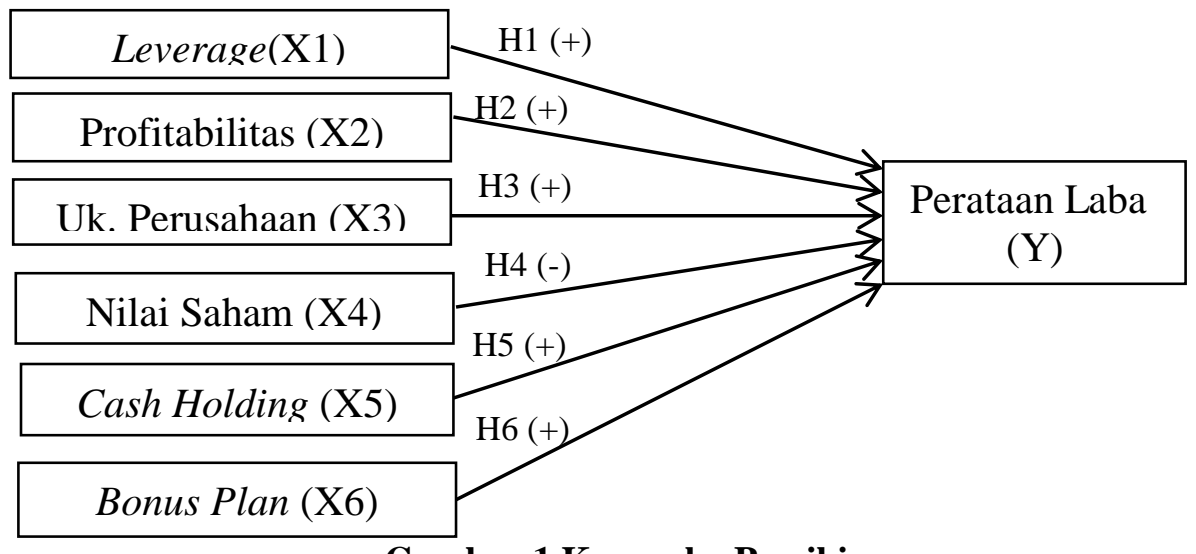

\section{Gambar 1 Kerangka Pemikiran}

METODE

Objek penelitian ini adalah perusahaan manufaktur subsektor industri barang konsumsi yang terdaftar pada Bursa Efek Indonesia (BEI) selama tahun 2016-2020. Sumber penelitian ini adalah sumber data sekunder. Teknik pengambilan sampel penelitian ini menggunakan metode purposive sampling, dengan populasi sebanyak 265 perusahaan. Kriteria sampel yang digunakan yaitu perusahaan industri barang konsumsi yang menyajikan laporan keuangan yang dipublikasikan di Bursa Efek Indonesia periode 2016-2020. Jumlah sampel akhir penelitian ini sebanyak 222 perusahaan.

Tabel 1

Definisi Operasional dan Pengukuran Variabel

\begin{tabular}{|c|l|c|}
\hline Variabel & \multicolumn{1}{|c|}{ Definisi } & \multicolumn{1}{|c|}{ Pengukuran } \\
\hline $\begin{array}{c}\text { Perataan Laba } \\
(\mathrm{Y})\end{array}$ & $\begin{array}{l}\text { Perataan laba merupakan praktik yang dilakukan } \\
\text { manajemen untuk mencapai tujuan dengan mengurangi } \\
\text { naik turunnya laba supaya terlihat baik dimata pihak } \\
\text { eksternal. (Choerunnisa dan Muslih, 2020) }\end{array}$ & Indeks Eckel $=\frac{\mathrm{CV} \Delta \mathrm{I}}{\mathrm{CV} \Delta \mathrm{S}}$ \\
\hline
\end{tabular}


Owner: Riset \& Jurnal Akuntansi

e-ISSN : 2548-9224 | p-ISSN : 2548-7507

Volume 6 Nomor 1, Januari 2022

DOI : https://doi.org/10.33395/owner.v6i1.539

\begin{tabular}{|c|c|c|}
\hline Leverage (X1) & $\begin{array}{l}\text { Penggunaan leverage yaitu untuk menunjukan bahwa } \\
\text { aset yang dimiliki perusahaan mampu membiayai } \\
\text { utang yang dimiliki perusahaan. (Revinsia, Rahayu, } \\
\text { dan Lestari, 2019) }\end{array}$ & $D A R=\frac{\text { Total Hutang }}{\text { Total Asset }}$ \\
\hline $\begin{array}{l}\text { Profitabilitas } \\
\text { (X2) }\end{array}$ & $\begin{array}{l}\text { Profitabilitas digunakan untuk mengetahui kemampuan } \\
\text { perusahaan dalam hal mencari laba dan juga mengukur } \\
\text { tingkat efektivitas. (Yulia, 2017) }\end{array}$ & $\begin{array}{l}\text { ROA } \\
=\frac{\text { Laba setelah pajak }}{\text { Total Asset }}\end{array}$ \\
\hline $\begin{array}{l}\text { Ukuran } \\
\text { Perusahaan } \\
\quad \text { (X3) }\end{array}$ & $\begin{array}{l}\text { Ukuran dalam suatu perusahaan yang mempunyai total } \\
\text { aset yang besar akan cenderung melakukan upaya } \\
\text { mendapatkan penilaian yang baik dari masyarakat, } \\
\text { investor, dan pemerintah. (Ditiya dan Sunarto, 2019) }\end{array}$ & Size $_{t}=$ Ln Total Asset $t$ \\
\hline $\begin{array}{l}\text { Nilai Saham } \\
\text { (X4) }\end{array}$ & $\begin{array}{l}\text { Nilai saham merupakan cerminan dari nilai } \\
\text { perusahaan, naik dan turunnya nilai pasar saham } \\
\text { dipengaruhi oleh feedback dari investor terhadap laba } \\
\text { perusahaan. (Mardiana dan Yulianasari, 2018) }\end{array}$ & $\mathrm{SV}=\frac{\text { Harga Saham }}{\text { Nilai Buku }}$ \\
\hline $\begin{array}{c}\text { Cash Holding } \\
\text { (X5) }\end{array}$ & $\begin{array}{l}\text { Cash holding merupakan kas yang dimiliki perusahaan } \\
\text { dengan sifatnya bukan jangka panjang melainkan } \\
\text { sifatnya jangka pendek, liquid, dan mudah sekali } \\
\text { dipindah tangankan. (Choerunnisa dan Muslih, 2020) }\end{array}$ & $\mathrm{CH}=\frac{\text { Kas }+ \text { Setara Kas }}{\text { Total Aset }}$ \\
\hline $\begin{array}{l}\text { Bonus Plan } \\
\text { (X6) }\end{array}$ & $\begin{array}{l}\text { Bonus plan merupakan imbalan yang diberikan kepada } \\
\text { pihak manajemen, apabila laba perusahaan mengalami } \\
\text { kenaikan atau dapat dikatakan apabila manajemen } \\
\text { mencapai target dalam tahun tersebut. (Nirmanggi dan } \\
\text { Muslih, 2020) }\end{array}$ & $\mathrm{BP}_{t}=L n$ Biaya Gaji $t$ \\
\hline
\end{tabular}

Sumber: Jurnal Publikasi Sinta dan Garuda

Teknik Analisis Data

Analisis Statistik Deskriptif

Analisis Statistik Deskriptif akan memberikan gambaran data yang dilihat dari nilai minimum, maksimum data, rata - rata (mean), dan standar deviasai (std) (Ghozali, 2018:19).

\section{Uji Normalitas}

Data diatribusikan normal jika nilai signifikannya lebih dari 0,05 atau 5\% hasil tersebut dapat dikatakan normal, begitupun sebaliknya (Ghozali, 2018:160). Uji normalitas pada penelitian ini dengan menggunakan analisis statistik yaitu dengan nilai Zskewness dan Zkurtosis dengan alpha 5\% (Ghozali, 2018:160).

\section{Uji Asumsi Klasik}

Uji Multikoleniaritas

Uji multikoleniaritas dapat dilihat dari nilai tolerance dan Varian Inflation Factor (VIF). Multikoleniaritas terjadi apabila nilai tolerance $<0,10$ atau nilai VIF $>10$ (Ghozali, 2018:103).

\section{Uji Heteroskedastisitas}

Cara mengetahui ada atau tidak nilai heterokedastisitas diperlukan uji glejser. Uji glejser mengusulkan untuk meregresi nilai absolut residual dari setiap variabel independen (Ghozali, 2018:134). Hal ini bisa dilihat dari nilai signifikansinya diatas $5 \%$ atau 0,05 .

\section{UjiAutokorelasi}

Hal ini muncul karena adanya satu observasi ke observasi lain yang terdapat residual tidak bebas. Uji Durbin Watson, menjelaskan adanya konstantadalam regresi yang tidak ada variabel lain antara variabel independen (Ghozali, 2018:110).

\section{Uji Kelayakan Model}

Uji F 
Uji $\mathrm{F}$ ini dilakukan untuk mengetahui nilai signifikansi $\mathrm{F}$ pada output hasil regresi dengan nilai signifikansinya yaitu 0,05 . Uji F dapat dikatakan fit apabila nilai signifikansinya lebih kecil dari 0,05 (Ghozali, 2018:98).

\section{Uji Koefisien Determinasi (Adjusted R2)}

Apabila nilai koefisien determinasi antara 0 dan 1 (Ghozali, 2018:98), koefisien determinasi 0 variabel independen sama sekali tidak mempunyai pengaruh terhadap variabel dependen. Apabila hasilnya semakin mendekati 1 , maka variabel independen berpengaruh terhadap variabel dependen.

\section{Uji Regresi Linier Berganda}

Analisis regresi linier berganda ini mempunyai tujuan mengetahui tujuan dari fungsi masing masing variabel independen terhadap variabel dependen. Menurut Ditiya dan Sunarto (2019) berikut ini adalah persamaan regresi yang digunakan dalam pengujian:

$$
Y 1=\alpha+b 1 x 1+b 2 x 2+b 3 x 3+b 4 x 4+b 5 x 5+b 6 x 6+\varepsilon
$$

Keterangan :

$\begin{array}{llll}\text { IS } & =\text { Income Smoothing } & \boldsymbol{x} \mathbf{3} & =\text { Ukuran perusahaan } \\ \boldsymbol{\alpha} & =\text { Konstanta } & \boldsymbol{x} \mathbf{4} & =\text { Penilaian saham } \\ \boldsymbol{b} & =\text { Koefisien Regresi } & \boldsymbol{x} \mathbf{5} & =\text { Cash holding } \\ \boldsymbol{x} \mathbf{1} & =\text { Leverage } & \boldsymbol{x} \mathbf{6} & =\text { Bonus plan } \\ \boldsymbol{x} \mathbf{2} & =\text { Profitabilitas } & \varepsilon & =\text { Eror }\end{array}$

\section{Uji Hipotesis (Uji Statistik t)}

Uji ini ditentukan jika tingkat signifikansi $<0,05$ maka dapat diartikan bahwa variabel independen mempengaruhi variabel dependen, dan jika tingkat signifikansi > 0,05 maka dapat diartikan bahwa variabel independen tidak mempengaruhi variabel dependen(Ghozali, 2018:96).

\section{Analisis Statistik Deskriptif}

HASIL

Tabel 1. Analisis Statistik Deskriptif sebelum Outlier

\begin{tabular}{|c|c|c|c|c|c|}
\hline & $\mathrm{N}$ & Minimum & Maximum & Mean & Std. Deviation \\
\hline DAR & 222 & ,0204 &, 8897 & ,394911 &, 1848821 \\
\hline $\mathrm{ROA}$ & 222 &,- 2140 & 9250 & ,083588 &, 1425030 \\
\hline SIZE & 222 & 14,4514 & 27,5122 & 21,527881 & 1,8077786 \\
\hline SV & 222 &,- 1567 &, 1733 & ,006947 & ,0219870 \\
\hline $\mathrm{CH}$ & 222 & ,0003 & ,6948 &, 116057 & , 1336377 \\
\hline BP & 222 & 11,7359 & 23,1745 & 18,551021 & 1,9001809 \\
\hline IE & 222 & 0017 & ,9995 & ,339519 & ,2259116 \\
\hline $\begin{array}{l}\text { Valid N } \\
\text { (listwise) }\end{array}$ & 222 & & & & \\
\hline
\end{tabular}

Sumber: Output SPSS 26

Berdasarkan tabel 1 menunjukan bahwa hasil analisis statistik deskriptif sebelum outlier dengan variabel dependen perataan laba (IE), variabel independen leverage (DAR), profitabilitas (ROA), ukuran perusahaan (SIZE), nilai saham (SV), cash holding $(\mathrm{CH})$, dan bonus plan (BP). Jumlah sampel yang diguunakan pada awal penelitian ditunjukan dengan N sebesar 222 perusahaan.

Tabel 2. Analisis Statistik Deskriptif setelahOutlier

\begin{tabular}{lcrrrr}
\hline & $\mathrm{N}$ & \multicolumn{1}{c}{ Minimum } & Maximum & \multicolumn{1}{c}{ Mean } & \multicolumn{1}{c}{ Std. Deviation } \\
\hline DAR & 142 &, 0204 &, 8897 &, 378809 &, 2165745 \\
ROA & 142 &, 0000 &, 8636 &, 112931 &, 1191634 \\
SIZE & 142 & 14,4657 & 27,5122 & 21,988449 & 1,8072233 \\
SV & 142 &, 0001 &, 0358 &, 004083 &, 0062243 \\
CH & 142 &, 0003 &, 6948 &, 134504 &, 1406116
\end{tabular}




\begin{tabular}{lrrrrr} 
BP & 142 & 11,8034 & 23,1745 & 19,142063 & 1,7272798 \\
IE & 142 &, 0017 &, 8826 &, 300979 &, 1400404 \\
$\begin{array}{l}\text { Valid N } \\
\text { (listwise) }\end{array}$ & 142 & & & & \\
\hline
\end{tabular}

Sumber: Output SPSS 26

Berikut ini penjelasan untuk tabel 2 setelah outlier:

Variabel IE menunjukan bahwa IE memiliki nilai mean sebesar 0,300979 dan standar deviasi sebesar 0,1400404. Nilai minimum variabel IE sebesar 0,0017terdapat pada perusahaan Kino Indonesia Tbk di tahun 2019, sedangkan nilai maksimum variabel IE sebesar 0,8826terdapat pada perusahaanPT. Tiga Pilar Sejahtera Food Tbk di tahun 2019.

Variabel DAR menunjukan bahwa DAR memiliki nilai mean sebesar 0,378809 dan standar deviasi sebesar 0,2165745. Nilai minimum variabel DAR sebesar 0,0204terdapat pada perusahaan Wismilak Inti Makmur Tbk di tahun 2018, sedangkan nilai maksimum variabel DAR sebesar 0,8897 terdapat pada perusahaan Tempo Scan Pasific Tbk di tahun 2018 .

Variabel ROA menunjukan bahwa ROA memiliki nilai mean sebesar 0,112931 dan standar deviasi sebesar 0,1191634. Nilai minimum variabel ROA sebesar 0,0000terdapat pada perusahaan PT Indofarma di tahun 2020. Sedangkan nilai maksimum variabel ROA sebesar 0,8636 terdapat pada perusahaan PT. Tiga Pilar Sejahtera Food Tbk di tahun 2019.

Variabel SIZE menunjukan bahwa SIZE memiliki nilai mean sebesar 21,988449 dan untuk standar deviasi sebesar 1,8072233. Nilai minimum variabel SIZE sebesar 14,4657terdapat pada perusahaan PT. Phapros Tbk di tahun 2020, sedangkan nilai maksimum variabel SIZE sebesar 27,5122 terdapat pada perusahaan PT. Indofood Sukses Makmur Tbk di tahun 2017.

Variabel SV menunjukan bahwa SV memiliki nilai mean atau rata - rata sebesar 0,00408 dan untuk standar deviasi sebesar 0,0062243. Nilai minimum variabel SV sebesar 0,0001 terdapat pada perusahaan PT. Budi Starch dan Sweeterner di tahun 2018, sedangkan nilai maksimum variabel SV sebesar 0,0358 terdapat pada perusahaan PT. Siantar Top di tahun 2016.

Variabel CH menunjukan bahwa $\mathrm{CH}$ memiliki nilai mean sebesar 0,134504 dan standar deviasi sebesar 0,1406116. Nilai minimum variabel $\mathrm{CH}$ sebesar 0,0003terdapat pada perusahaan PT. Wahana Interfood Indonesia di tahun 2020, sedangkan nilai maksimum variabel $\mathrm{CH}$ sebesar 0,6948 terdapat pada perusahaan PT. Tempo Scan Pasific Tbk di tahun 2018.

Variabel BP menunjukan bahwa BP memiliki nilai mean sebesar 19,142063 dan standar deviasi sebesar 1,7272798. Nilai minimum variabel BP sebesar 11,8034terdapat pada perusahaan PT. Phapros di tahun 2020, sedangkan nilai maksimum variabel BP sebesar 23,1745 terdapat pada perusahaan PT. Uniliver Indonesia Tbk di tahun 2020.

\section{Uji Normalitas}

Tabel 3. Uji Normalitas sebelum Outlier

\begin{tabular}{lrrrrr}
\hline & $\mathrm{N}$ & \multicolumn{2}{c}{ Skewness } & \multicolumn{2}{c}{ Kurtosis } \\
\cline { 2 - 6 } & Statistic & Statistic & Std. Error & Statistic & Std. Error \\
\hline Unstandardized & 222 & 4,576 &, 163 & 29,108 &, 325 \\
Residual & & & & & \\
Valid N (listwise) & 222 & & & &
\end{tabular}


Berdasarkan uji normalitas diatas, dapat dilihat bahwa nilai skewness dan kurtosis lebih besar dari 1,96. Nilai skewness diatas sebesar 27,835 $(4,576: 0,164)>1,96$ dan nilai kutosis $88,529(29,108: 0,329)>1,96$. Maka dalam hal ini dapat dikatakan bahwa data yang diteliti tidak berdistribusi normal sehingga perlu dilakukan outlier pada data - data yang nilainya ekstrim supaya data dapat berdistribusi normal. Berikut ini adalah uji normalitas setelah outlier:

Tabel 4. Uji Normalitas setelah Outlier

\begin{tabular}{lccccc}
\hline & $\mathrm{N}$ & \multicolumn{2}{c}{ Skewness } & \multicolumn{2}{c}{ Kurtosis } \\
\cline { 2 - 6 } & Statistic & Statistic & Std. Error & Statistic & Std. Error \\
\hline Unstandardized & 142 &,- 027 &, 203 &,- 025 &, 404 \\
Residual & & & & & \\
Valid N (listwise) & 142 & & & & \\
\hline Sumber: Output SPSS 26 & & & &
\end{tabular}

Berdasarkan uji normalitas diatas, dapat dilihat bahwa nilai skewness dan kurtosis lebih kecil dari 1,96. Nilai skewness sebesar $-0,131<1,96$ dan nilai kutosis $-0,069<1,96$. Maka dalam hal ini dapat dikatakan bahwa data tersebut telah menunjukan hasil berdistribusi normal.

\section{Uji Asumsi Klasik \\ Uji Multikolenieritas}

Tabel 5. Uji Multikoleniaritas

\begin{tabular}{|c|c|c|c|}
\hline & \multirow{2}{*}{ Model } & \multicolumn{2}{|c|}{ Collinearity Statistics } \\
\hline & & Tolerance & VIF \\
\hline \multirow[t]{7}{*}{1} & (Constant) & & \\
\hline & DAR &, 723 & 1,384 \\
\hline & ROA & 684 & 1,461 \\
\hline & SIZE & ,201 & 4,974 \\
\hline & SV & ,891 & 1,123 \\
\hline & $\mathrm{CH}$ & ,793 & 1,260 \\
\hline & $\mathrm{BP}$ & ,194 & 5,156 \\
\hline
\end{tabular}

Sumber: Output SPSS 26

Berdasarkan tabel 5 dapat dilihat masing - masing nilai tolerancevariabel independen tidak ada yang kurang dari 0,10 . Pada nilai variabel DAR nilai tolerance sebesar $0,723>0,10$, nilai variabel ROA nilai tolerance sebesar $0,684>0,10$, nilai variabel SIZE nilai tolerance sebesar 0,201 >0,10, nilai variabel SV nilai tolerance sebesar $0,891>0,10$, nilai variabel $\mathrm{CH}$ nilai tolerance sebesar $0,793>0,10$, dan untuk nilai variabel BP nilai tolerance sebesar 0,193 > 0,10 .

Hasil uji tersebut juga terjadi pada nilai Variance Inflation Factor (VIF). Dapat dilihat bahwa masing - masing nilai Variance Inflation Factor (VIF) tidak ada yang lebih dari 10. Pada nilai variabel DAR nilai tolerance sebesar $1,384<10$, nilai variabel ROA nilai tolerance sebesar $1,461<10$, nilai variabel SIZE nilai tolerance sebesar $4,974<10$, nilai variabel SV nilai tolerance sebesar $1,123<10$, nilai variabel $\mathrm{CH}$ nilai tolerance sebesar $1,260<10$, dan nilai variabel BP nilai tolerance sebesar 5,156 < 10. Sehingga dapat disimpulkan bahwa model regresi untuk penelitian ini tidak ditemukan masalah multikolinearitas antar variabel independen.

\section{Uji Heteroskedastisitas}

Tabel 6. Uji Heterokedastisitas

\begin{tabular}{llr}
\hline \multicolumn{2}{c}{ Model } & \multicolumn{2}{c}{ Sig. } \\
\hline 1 & (Constant &, 007 \\
& DAR &, 202 \\
& ROA &, 185 \\
& SIZE &, 832 \\
& SV &, 291
\end{tabular}


a. Dependent Variable: ABSRES

Sumber: Output SPSS 26

Berdasarkan tabel 6 menunjukan hasil bahwa semua variabel dalam penelitian ini mempunyai probabilitas signifikansi lebih dari $5 \%$ atau 0,05 . Jadi dapat disimpulkan model regresi dalam penelitian ini tidak mengandung adanya heterokedastisitas.

\section{UjiAutokorelasi}

Tabel 7. Uji Autokorelasi

\begin{tabular}{lrrrrr} 
Model & $\mathrm{R}$ & $\mathrm{R}$ Square & Adjusted R Square & Std. Error of the Estimate & Durbin-Watson \\
\hline 1 &, $633^{\mathrm{a}}$ &, 400 &, 374 &, 1108185 & 1,869
\end{tabular}

a. Predictors: (Constant), BP, DAR, SV, CH, ROA, SIZE

b. Dependent Variable: IE

Sumber: Output SPSS 26

Berdasarkan tabel7 menunjukan bahwa hasil dari batas bawah (dl) sebesar 1,6388 dan batas atas (du) sebesar 1,7798, sehingga 4-du yaitu sebesar 2,1854 dan untuk 4-dl sebesar 2,3612. Maka dapat diartikan bahwa du $<\mathrm{dw}<4$-du atau 1,814 < 1,869 <2,1854, dimana posisi Durbin Watson yaitu sebesar 1,869 terletak pada daerah tidak ada korelasi. Hal ini dapat disimpulkan bahwa model regresi pada penelitian ini terbebas dari autokorelasi.

\section{Uji Kelayakan Model}

Uji F

Tabel 8. Uji F

\begin{tabular}{llrrrrr}
\hline Model & & Sum of Squares & df & Mean Square & F & Sig. \\
\hline 1 & Regression & 1,107 & 6 &, 185 & 15,028 &, $000^{\mathrm{b}}$ \\
& Residual & 1,658 & 135 &, 012 & & \\
& Total & 2,765 & 141 & & &
\end{tabular}

a. Dependent Variable: IE

b. Predictors: (Constant), BP, DAR, SV, CH, ROA, SIZE

Sumber: Output SPSS 26

Berdasarkan tabel 8 menunjukan bahwa diperoleh hasil nilai $\mathrm{F}$ hitung sebesar 15,028 dengan nilai signifikansinya yaitu sebesar 0,000 . Hal ini memberikan arti nilai signifikansi lebih kecil dari 0,05 dan dapat dikatakan bahwa variabel independen dalam model regresi ini secara bersama - sama berpengaruh terhadap variabel dependen yaitu perataan laba.

Uji Koefisien Determinasi (Adjusted R2)

\section{Tabel 9}

Uji Koefisien Determinasi (Adjusted R2)

\begin{tabular}{llrrr}
\hline Model & $\mathrm{R}$ & $\mathrm{R}$ Square & Adjusted R Square & Std. Error of the Estimate \\
\hline 1 &, $633^{\mathrm{a}}$ &, 400 &, 374 &, 1108185
\end{tabular}

a. Predictors: (Constant), BP, DAR, SV, CH, ROA, SIZE

Sumber: Output SPSS 26

Berdasarkan tabel 9 menunjukan hasil bahwa nilai Adjusted $R$ Square (R2) sebesar 0,374. Hal ini berarti bahwa variabel dependen (IE) dapat dijelaskan secara keseluruhan oleh enam independen yaitu DAR, ROA, SIZE, SV, CH, BP sebesar 37,4\%. Sedangkan 62,6\% (100\% $37,4 \%$ ) dijelaskan oleh variabel - variabel lainnya diluar model penelitian ini.

\section{Uji Regresi Linier Berganda}

Tabel 10. Uji Regressi Linier Berganda dan Uji Hipotesis

\begin{tabular}{cccccc} 
Model & \multicolumn{2}{c}{ Unstandardized Coefficients } & Standardized Coefficients & \multirow{2}{*}{ t } & Sig. \\
\cline { 2 - 3 } & B & Std. Error & Beta & \\
\hline
\end{tabular}


Owner: Riset \& Jurnal Akuntansi

e-ISSN : 2548-9224 | p-ISSN : 2548-7507

Volume 6 Nomor 1, Januari 2022

DOI : https://doi.org/10.33395/owner.v6i1.539

\begin{tabular}{rlrrrrr}
\hline 1 & (Constant) &, 221 &, 120 & & 1,833 &, 069 \\
DAR &,- 045 &, 051 &,- 070 &,- 889 &, 376 \\
& ROA &, 722 &, 095 &, 614 & 7,626 &, 000 \\
SIZE &, 010 &, 012 &, 131 &, 878 &, 381 \\
& SV &,- 791 & 1,589 &,- 035 &,- 498 &, 619 \\
& CH &, 175 &, 075 &, 176 & 2,353 &, 020 \\
& BP &,- 012 &, 012 &,- 146 &,- 966 &, 336
\end{tabular}

. Dependent Variable: IE

Sumber: Output SPSS 26

Berdasarkan tabel 10 dapat diketahui bahwa untuk variabel leverage (DAR) nilai koefisien sebesar $-0,045$, untuk variabel profitabilitas(ROA) nilai koefisien sebesar 0,722 , untuk variabel ukuran perusahaan(SIZE) nilai koefisien sebesar 0,010, untuk variabel cash holding $(\mathrm{CH})$ nilai koefisien sebesar 0,175 , dan untuk variabel bonus plan (BP) nilai koefisien -0,012. Dari hasil uji regresi linier berganda diatas maka dapat disusun persamaan sebagai berikut:

$\mathrm{Y} 1=0,221-0,045 \mathrm{DAR}+0,722 \mathrm{ROA}+0,010 \mathrm{SIZE}-0,791 \mathrm{SV}+0,175 \mathrm{CH}-0,012 \mathrm{BP}+\varepsilon$

\section{Uji Hipotesis (Uji Statistik t)}

\section{Pengujian Pengaruh Leverage terhadap Perataan Laba}

$\mathrm{H} 1$ : Leverageberpengaruh positif signifikan terhadap perataan laba

Berdasarkan hasil pada tabel 10 dapat diketahui nilai dari t hitung variabel DAR sebesar 0,889 dengan nilai signifikansi sebesar $0,376>0,05$. Hal ini artinya bahwa leverage tidak berpengaruh terhadap perataan laba, sehingga hipotesis pertama (H1) ditolak.

\section{Pengujian Pengaruh Profitabilitas terhadap Perataan Laba}

$\mathrm{H} 2$ : Profitabilitas berpengaruh positif signifikan terhadap perataan laba

Berdasarkan hasil pada tabel 10 dapat diketahui nilai dari t hitung variabel ROA sebesar 7,626 dengan nilai signifikansi sebesar $0,000<0,05$. Hal ini artinya bahwa profitabilitas berpengaruh positif signifikan terhadap perataan laba, sehingga hipotesis kedua (H2) diterima.

\section{Pengujian Pengaruh Ukuran Perusahaan terhadap Perataan Laba}

\section{H3 : Ukuran Perusahaan berpengaruh positif signifikan terhadap perataan laba}

Berdasarkan hasil pada tabel 10 dapat diketahui nilai dari t hitung variabel SIZE sebesar 0,878 dengan nilai signifikansi sebesar 0,381 >0,05. Hal ini artinya bahwa ukuran perusahaan tidak berpengaruh terhadap perataan laba, sehingga hipotesis ketiga (H3) ditolak.

Pengujian Pengaruh Nilai Saham terhadap Perataan Laba

H4 : Nilai Saham berpengaruh negatif signifikan terhadap perataan laba

Berdasarkan hasil pada tabel 10 dapat diketahui nilai dari t hitung variabel SV sebesar -0,498 dengan nilai signifikansi sebesar 0,619>0,05. Hal ini artinya bahwa nilai saham tidak berpengaruh terhadap perataan laba, sehingga hipotesis keempat (H4) ditolak.

\section{Pengujian Pengaruh Cash Holding terhadap Perataan Laba}

H5 : Cash holding berpengaruh positif signifikan terhadap perataan laba

Berdasarkan hasil pada tabel 10 dapat diketahui nilai dari t hitung variabel $\mathrm{CH}$ sebesar 2,353 dengan nilai signifikansi sebesar $0,020<0,05$. Hal ini artinya bahwa cash holding berpengaruh positif signifikan terhadap perataan laba, sehingga hipotesis kelima (H5) diterima.

\section{Pengujian Pengaruh Bonus Plan terhadap Perataan Laba}

H6 : Bonus plan berpengaruh positif signifikan terhadap perataan laba 
Berdasarkan hasil pada tabel 10 dapat diketahui nilai dari thitung variabel BP sebesar -0,966 dengan nilai signifikansi sebesar 0,336>0,05. Hal ini artinya bahwa bonus plan tidak berpengaruh signifikan terhadap perataan laba, sehingga hipotesis keenam (H6) ditolak.

\section{Pengaruh Leverage Terhadap Perataan Laba \\ PEMBAHASAN}

Penelitian ini membuktikan bahwa leverage tidak berpengaruh terhadap perataan laba, sehingga hipotesis pertama ditolak. Teori agensi yang menjelaskan bahwa manajer lebih mengetahui kondisi perusahaan dibandingkan dengan kreditur. Tingkat utang yang cenderung tinggi manajer akan melakukan pengelolaan atas laba untuk mengindari pelanggaran perjanjian utang yang telah disepakati (Setyani dan Wibowo, 2019). Hasil penelitian ini didukung oleh penelitian Revinsia, Rahayu, dan Lestari (2019); Setyani dan Wibowo (2019); Dewi dan Suryanawa (2019); dan Mardiana dan Yulianasari (2018) yang menyatakan leverage tidak berpengaruh terhadap perataan laba.

\section{Pengaruh Profitabilitas Terhadap Perataan Laba}

Penelitian ini membuktikan bahwa profitabilitas berpengaruh positif dan signifikan terhadap perataan laba, sehingga hipotesis kedua diterima. Hal ini sejalan dengan teori agency yang mengemukakan bahwa manajer akan dinilai memiliki kinerja yang baik ketika perusahaan mempunyai profitabilitas yang tinggi, ini berarti bahwa manajer bekerja sesuai dengan keinginan pemilik perusahaan. Apabila perusahaan memiliki kemampuan memperoleh laba kecil dan tidak stabil, akan membahayakan kamampuan perusahaan dalam kelangsungan jangka panjang (Ditiya dan Sunarto, 2019). Hasil penelitian ini didukung oleh penelitian yang dilakukan Ditiya dan Sunarto (2019); dan Yulia (2017) yang menyatakan bahwa profitabilitas berpengaruh positif dan signifikan terhadap perataan laba.

\section{Pengaruh Ukuran Perusahaan Terhadap Perataan Laba}

Penelitian ini membuktikan bahwa ukuran perusahaan tidak berpengaruh signifikan terhadap perataan laba, sehingga hipotesis ketiga ditolak. Berdasarkan teori akuntansi positif tentang hipotesis biaya politik menyatakan bahwa, manajer akan berusaha menurunkan laba apabila diikuti dengan tingginya biaya politik perusahaan. Ketertarikan investor membuat jumlah shareholder dalam perusahaan meningkat, sehingga manajer selalu memberikan upaya mengurangi kesenjangan informasi antara agen dan prinsipal melalui penerapan GCG (Dewi dan Suryanawa, 2019) akan menyebabkan perusahaan besar cenderung tidak melakukan perataan laba. Hasil penelitian ini didukung oleh penelitian yang dilakukan Choerunnisa dan Muslih (2020); Setyani dan Wibowo (2019)yang menyatakan bahwa ukuran perusahaan tidak memberikan pengaruh terhadap perataan laba.

\section{Pengaruh Nilai Saham Terhadap Perataan Laba}

Penelitian ini membuktikan bahwa nilai saham tidak berpengaruh terhadap perataan laba, sehingga hipotesis keempat ditolak. Artinya, nilai saham yang tinggi akan membuat perusahaan untuk tidak melakukan perataan laba. Berdasarkan teori signal, perusahaan akan mendapatkan berita atau sinyal yang baik dari investor apabila perusahaan memiliki informasi yang baik pula. Hasil penelitian ini didukung oleh penelitian yang dilakukan Dewi, Mukhtaruddin, dan Prayudha (2018) yang menyatakan bahwa nilai saham tidak memberikan pengaruh terhadap perataan laba.

\section{Pengaruh Cash Holding Terhadap Perataan Laba}

Penelitian ini membuktikan bahwa cash holding memberikan pengaruh positif dan signifikan terhadap perataan laba, sehingga hipotesis kelima diterima. Hasil tersebut didukung dengan adanya agency theory, yang menyatakanadanya keinginan manajemen untuk menguasai kas yang ada di perusahaan. Cash holding yang mudah dikendalikan manajer, mudah dipindahtangankan, dan sifat cash holding yang liquid membuat kas mudah di sembunyikan atau digunakan untuk tindakan yang tidak semestinya salah satunya tindakan perataan laba (Revinsia, Rahayu, dan Lestari; 2019). Hasil penelitian ini didukung oleh penelitian yang dilakukan 
Nirmanggi dan Muslih (2020) dan Revinsia, Rahayu, dan Lestari (2019) yang menyatakan bahwa cash holding memberikan pengaruh positif signifikan terhadap perataan laba.

\section{Pengaruh Bonus Plan Terhadap Perataan Laba}

Penelitian ini membuktikan bahwa bonus plan tidak berpengaruh yang signifikan terhadap perataan laba, sehingga hipotesis keenam ditolak. Penelitian ini tidak mendukung agency theory yang menyatakan pihak manajer yang mempunyai kepentingan untuk memperoleh bonus, melakukan peningkatan bonus yang diterima dengan praktik perataan laba. Tidak berpengaruhnya bonus plan terhadap perataan laba itu berarti bahwa bonus plan bukan faktor penting yang dilihat manajemen untuk melakukan perataan laba (Nirmanggi dan Muslih, 2020). Hasil penelitian ini didukung oleh penelitian Nirmanggi dan Muslih (2020) yang menyatakan bahwa bonus plan tidak memberikan pengaruh yang signifikan terhadap perataan laba.

\section{KESIMPULAN}

Berdasarkan hasil analisis yang telah dilakukan pada perusahaan manufaktur subsektor industri barang konsumsi yang terdaftar di BEI pada tahun 2016 - 2020 maka dapat diambil kesimpulan bahwaleverage tidak berpengaruh terhadap perataan laba, profitabilitas berpengaruh positif terhadap perataan laba, ukuran perusahaan tidak berpengaruh terhadap perataan laba, nilai saham tidak berpengaruh terhadap perataan laba, cash holding berpengaruh positif signifikan terhadap perataan laba, dan bonus plan tidak berpengaruh terhadap perataan laba.

\section{REFERENSI}

Aziz. (2021, Mei 25). Pasardana. Diakses September 22, 2021, from Pasardana.id: https://pasardana.id/news/2021/5/25/ades-raup-laba-rp135-miliar-pada-tahun-2020/\#

Choerunnisa, E., \& Muslih, M, 2020. Pengaruh Komite Audit, Cash Holding, Dan Ukuran Perusahaan Terhadap Perataan Laba. Jurnal Pendidikan Akuntansi Indonesia, 18(2), 77 92.

Dewi, A. M., \& Suryanawa, I. K, 2019. Pengaruh Leverage, Bonus Plan, Ukuran Perusahaan, Dan Profitabilitas Pada Praktik Perataan Laba. E-Jurnal Akuntansi Universitas Udayana, 26(1), $58-84$.

Dewi, K., Mukhtaruddin, \& Prayudha, I. A, 2018. Income Smoothing And Market Performance : Empirical Study on Manufacturing Companies Listed in Indonesian Stock Exchange. Invesment Management and Financial Innovation, 15(1), 106 - 119.

Ditiya, Y. D., \& Sunarto, 2019. Ukuran Perusahaan, Profitabilitas, Financial Leverage, Book Tax Differences Dan Kepenilikan Publik Terhadap Perataan Laba (Studi Empiris Perusahaan Manufaktur yang terdaftar di BEI periode 2014 - 2017). Dinamika Akuntansi, Keuangan, dan Perbankan, 8(1), 51 - 63.

Ghozali, I.2018. Aplikasi Analisis Multivariate Denggan Program IBM SPSS 25. Semarang: Badan Penerbit Universitas Diponegoro.

Jensen, M. C., \& Meckling, J. 1976. Theory of the firm: Managerial Behavior, Agency Costs and Owner Structure. Jurnal of Financial Economics, 305 - 360.

Mardiana, P., \& Yulianasari, N, 2018. Pengaruh Nilai Saham, Financial Leverage, Dan Pajak Penghasilan Terhadap Perataan Laba (Studi Kasus Perusahaan Manufaktur yang terdaftar di Bursa Efek Indonesia tahun 2012 - 2016). Jurnal Akuntansi Unihaz, 1(2), 31 - 38. 
Natalie, N., \& Astika, I. B, 2016. Pengaruh Cash Holding, Bonus Plan, Reputasi Auditor, Profitabilitas Dan Leverage Pada Income Smoothing. E-Jurnal Akuntansi Universitas Udayana, 15(2), 943 - 972.

Nirmanggi, I. P., \& Muslih, M, 2020. Pengaruh Operating Profit Margin, Cash Holding, Bonus Plan, dan Income Tax terhadap Perataan Laba. Jurnal Ilmiah Akuntansi, 5(1), 25 - 44.

Nugroho, S., \& Darsono, 2015. Pengaruh Kompensasi, Kepemilikan Manajerial, Diversifikasi Perusahaan, Dan Ukuran Kap Terhadap Manajemen Laba. Diponegoro Journal Sciences, $4(3), 1-13$.

Putra, R. A., \& Suardana, 2016. Pengaruh Varian Nilai Saham, Kepemilikan Publik, Dan Der Pada Praktik Perataan Laba. E-jurnal Akuntansi Universitas Udayana, 2188 - 2215.

Putri, P. D., \& Yudowati, S, 2018. PENGARUH FINANCIAL Leverage, Cash Holding, Dan Roa Pada Income Smoothing Di Bursa Efek Indonesia. E-Jurnal Akuntansi Universitas Udayana, 22(3), 1936 - 1964.

Revinsia, V. S., Rahayu, S., \& Lestari, T. U, 2019. Pengaruh Cash Holding, Profitabilitas, Dan Leverage Terhadap Pertaan Laba (Studi Kasus Perusahaan Manufaktur yang terdaftar di Bursa Efek Indonesia Tahun 2013 -2017). Jurnal Aksara Public, 3(1), 127 - 141.

Setyani, A. Y., \& Wibowo, E. A, 2019. Pengaruh Financial Leverage, Company Size, Dan Profitabilitas Terhadap Praktik Perataan Laba (Income Smoothing) Pada Perusahaan Manufaktur Yang Terdaftar Di Bursa Efek Indonesia. Research Fair Unisri, 3(1), 76 - 91.

Spence, M, 1973. Job Market Signalling. The Quarterly Journal of Economics, 87(3), 355 - 374.

Watts, R. L., \& Zimmerman, J. L, 1978. Toward a Positive Theory of the Determination of Accounting Standards. The Accounting Review, 53(1), 112 - 134.

Wiagustini, N. L. 2014. Manajemen Keuangan. Denpasar: Udayana Univesity Press.

Yulia, M, 2017. Pengaruh Ukuran Perusahaan, Profitabilitas, Financial Leverage, dan Nilai Saham Terhadap Perataan Laba. Jurnal Akuntansi UNP, 1 - 24.

Yusrilandari, L. P, 2016. Pengaruh Profitabilitas, Kepemilikan Manajerial, Dan Ukuran Perusahaan Terhadap Manajemen Laba. E-Proceeding of Management, 3(3), 3159 3167.

Y. Safitri, Abrar, \& E. B. Santoso. 2018. Peran Corporate Social Responsibility Dalam Memoderasi Pengaruh Profitabilitas, Leverage, Dan Likuiditas Terhadap Nilai Perusahaan. Journal Of Accounting, 4(4). 